FC103 Psychopathology and psychotherapies

\section{NARCISSISM AND MOTHERHOOD}

J-B, Dethieux, I Abadic, K. Grandjean, H. Szumman, J.P. Raynaud, P. Moron. Service de Psychiatrie de Psychologle médicale, Hopial la Grave, Place Lange 31054 Toulouse Cedex, France.

This study supported by the INSERM CFF 9406 (National Institute of Health and Medical Research) focuses on the difluculties of articulation between the narciscistic libido and the objectal libido during pregnancy indicating a developmental disonder of the original narcissiscic crisis Our working hypothesis is that erticulation between narcissistic and objectal investment is relaced to the quality of the eariy interactions between the mother-to-be and her own mother. The population consists of 73 pregnant women recruited in an obstetric-gynaccological department of a large metropolitan hospital in Toulouse, France. Subjects were inkerviewed Iwice during pregnancy and once in the post-partum period for a coul of three evaluations. Evalualions included: 1) semi-directed interview examining psychopathologic functioning on the narcissistic level; 2) The Objective Social Prevention Inventory (OPSI) (Kipper and Zigier-Shani, 1976) exploring four elements of psychological expentence of the pregnancy (perceptions of: feminure gender, motherhood, mantal relations. meternal relations): 3) The Hospital Anxiety Depression Scale (HAD) (Zigmund and Snaith, 1983); 4) The EVAN Questionnaire (Visual Aralog Scale of Psychiatric Disorders, Narcissistic Level). This tool seeks to explore the semiological elements of an isolared narcissistic crisis over time during pregnancy. It is a non-standardized, non-validated tool and S) The Pitu Querstionnaire and the Edinburgh Post-Natal Depression Scale (Cox) examining the presence of depressive disorders during the post-pantum period. This audy also examines the predictability of certain depressive docompensations during the post-partum period, with particular attention towards preventive intereventions. Our results indicale: 1, that the subjects presenting disorder in the development of and surpassing of the narcissistic crisis, as idencified by clinical evaluation and high score on the EVAN Quescionnaire, exhibit a relational deficit with their own mothers as well as higher kevels of anxiery and 2. that those subjects seem no be more at risk for anxious and depressive manfestations during the post-partum period.
FC105 Psychopathology and psychotherapies DREAMS AND IMAGINARY ACTIVITY IN DEPRESSED PATIENTS

R. Giachetti, L. Schmitt, L. Lignac, M. Bensoussan. C.H.U. Purpan, Psychiatric Hospital Casselardit, Place du Docteur Baylac, Toulouse. France.

Dream activity, equivalents in wide-awake life and their perceptions are compared between depressed subjects and controls. Recently, $K$. M. Beauchernin (1995) indicates that dream activity is dependent on mood state. Depressed people are 30 hospitalised unipolar pauents (DSM-IV). The control group is a random sample of 307 people ranging from 18 to 80 years old. All the subjects answered an analogue scale questionnaire including 11 items such as frequency, content of dreams, emotions, interest in dreams, daydreaming, magical thought, creativity, awareness of spatiotemporality. The efficiency of the imaginary's function of depressed subjects appears very inferior to that of controls $(p<0.01 \%)$. The most disciminant questions concern frequency of dream $(\mathrm{P}<1 \%)$, content of dream $(\mathrm{P}<0.01 \%)$, interest in dream $(P<1 \%)$, questions about dream $(P<0.1 \%)$. The function of imaginery is all the more efficient when the subject is young. In the control group, women tend to dream more frequendy than men (dream of ten and rather often; women: $70.9 \%$, men: $56 \%$ ) and question their dreams more than men (women: $50.7 \%$, men: 31\%). As nighmares are known as symptoms of depression, this study shows that dream and imaginary are significantly impoverished in depressed patients.

\section{FC104 Psychopathology and psychotherapies}

Etude d'une population d'MM intégrée dans une Institution Oémédicaliste aprés un séjour prolongé en hoptta 1 Psychiatrique. G. Galli Carminati et $\mathrm{J}$. Moura-Serra.

Dans cette étude, nous présentons les caractéristiques d'une population d'HM hospitalisés a long terme qui a pu ètre intégrée dans une Institution Socio-Educative Démédical isée. Les 7 patients présentaient le diagnostic de Retard mental profond. Nous définis sons le Retard mental come un fonctionnement intellectuel géneral signif. au-dessous de la moyenne avec déficit dans les comportements adaptatifs qui se manifestent pdt la periode du develop. $L$ 'age des patients êtatent compris entre 24 et $53 \mathrm{a}$. au moment de 1 'intégration et $11 \mathrm{~s}$ avalent éte hosp. pdt une période en moyenne sup. a $10 \mathrm{a}$. Les patients présentaient une polypathologie associéo au $\mathrm{RM}^{*}$ sur le plan somatique. Nous avons evalué la presence de troubles du comportement avec I'ABC - The Aberrant Behavour Checkifst. 4 types de Facteurs ont été consideres:

Facteur I (irritation, agitation, pleurs) avec 15 items;

Fectnisr II (1étargie, retrait social) avec 16 items:

Facteur Ill (comportement steréotypés) avec 7 items:

Facteur IV (hyper activite, inadequation) avec 16 items:

Facteur $Y$ (langage ou paroles inapropriee) avec 4 items;

L'échelle de gravite est de 0 a 3 ( 0 = aucun probième; $1=1$ jéger; 2= moyen: 3= grave).

La prêsence d'un pattern symptomatologique charge indique la nécessité d'un soutien psychiatrique tout au long du processus d'insertion en milieu dẽmédical ise pour des patients hospitalises a long terme dont les troubles du comportement constituent un tableau de gravite moyenne - grave.

La coordination des soins restent la clef de voúte d'une démarche d'integration en institution démedicalisee et rend possible le projet de réhabilitation en milieu Soc10-Educatif.

$\star A B C$, The Aberrant Behaviour Checklist: A Behaviour Rating Scale for the Assessement of treatment effects. M.G. Aman and other-American Journal of Mental Deficiency. 1985, Vol 89 n.4-485,491.

\section{FC106 Psychopathology and psychotherapies}

\section{PERSONALITY AND PSYCHOPATHOLOGICAL FACTORS} ASSOCIATED WITH GENDER IDENTITY DISORDERS

Becker H. Hartmann U.

Department of Clinical Psychiatry and Psychotherapy

Medical School Hannover, 30623 Hannover, Germany

OBJECTIVE: In recent years there has been an increasing recognition of the complexity and beterogeneity of gender identity disorders and the term "transsexualism" has been dismissed as a distinct diagnostic category in DSM IV. To enhance knowledge on prognostical predictors in this population requesting or seriously considering sex reassignment surgery (SRS) a prospective study was initiated. In their pnmary evaluanon the authors focussed on personality and psychopathological factors.

METHODS: This presentation depicts relevant data acquired in intual assessment of 30 gender dysphonc patients. The standardized evaluation procedure included clinical interviews, a struchural interview according to concepts of Kernberg and self-developed and standardized psychometric questionnaires including the MMPI, 16 PF, Rosenzwesg PFT. Narcissism Inventory, and AGI and CGF (Blanchard)

RESULTS: 23 male to female and 7 female to male patients were reviewed, but for statistical reasons only biological males were analysed Significant narcissistic pathology could be identified in most of the sampled gender dysphorics, but regulation-modes and psychopatological aspects afflicted by this pathology differed widely The fundamental problem was identity and the self in general.

CONCLUSION: Preliminary results underline critucal statements urging for differential diagnostic evaluation of gender problems and the importance of identifying subtypes combined with differenciated treatment Combined with aspects of gender development and sexual ontentation psychopatological factors and the different modes of self-regulation appear to be relevant. 